\section{Contributors}

\section{Mike Fitzpatrick}

fitz@easynet.co.uk

Marie Hickinbotham is a Specialist Occupational Health Nurse Advisor who runs her own Occupational

Health Business. She is currently the part-time Course Director for the

Undergraduate Occupational Health courses over at Warwick University. mariehickinbotham@hotmail.com

Majid Rehman Khan is a locum GP and senior clinical fellow at Warwick Medical School (Developing a course in 'Mindful practice') with interests in Eastern philosophy

existentialism/spirituality and applications to general practice. majidrkhan@hotmail.com

Edin Lakasing is a GP in

Chorleywood, Hertfordshire, a Trainer on the Watford Vocational Training

Scheme, and Undergraduate Tutor to University College Hospital and Imperial College Medical Schools, London.

edin.lakasing@chorleywoodhealth centre.nhs.uk

\section{Michael Lasserson}

mlasserson@hotmail.com

Kamal R Mahtani is a Foundation Year 2 Honorary Clinical Academic Fellow at the Department of Primary Care and Population Sciences,

University College London.

krmahtani@hotmail.com

Andrew Papanikitas is a GP and PhD Student at the Centre for Biomedicine and Society, King's College London.

andrew.papanikitas@kcl.ac.uk

Neil Richardson

Neil.Richardson@kirklees.nhs.uk

Joe Rosenthal

j.rosenthal@pcps.ucl.ac.uk

Surinder Singh

rmjlssi@ucl.ac.uk

\title{
The Guy Fawkes of Tavistock Square
}

The former Merseyside GP Lennox Johnston, whose story is told in Christopher Snowdon's fascinating new history of anti-smoking campaigns, was in many ways a man ahead of his time. ${ }^{1}$ Following his personal researches into nicotine in the 1930s (which involved the self administration of dangerously toxic quantities), he pioneered the notion of nicotine addiction as the root of the evil of persistent smoking. In a paper published in the Lancet in 1942 he identified smoking as the cause of the upsurge of lung cancer and he always resented the primacy given to Doll and Hill's later work in this field. In a remarkable anticipation of current fashions, in 1945 he referred to a 'pandemic of smoking'. ${ }^{2}$ Already a committed temperance campaigner, Johnston also proposed legislation to ban smoking.

Yet, at a time when many doctors smoked and the BMJ still carried cigarette advertisements, some featuring doctors' endorsements for particular brands, $\mathrm{Dr}$ Johnston's theories and his demands for the prohibition of tobacco and alcohol were ignored and he was ostracised. Although he continued to pursue his campaign against 'tobaccoism' into the 1970s, he remained a marginal figure and is now long forgotten. Dismissed in his own lifetime as a fanatic, Lennox Johnston would today find himself in the mainstream of the medical profession. In 2003 the Lancet published an editorial demanding a total ban on the sale of tobacco. ${ }^{3}$ Last month, the BMA issued the latest in a series of demands for increasingly draconian measures against the advertising, promotion, and sale of alcohol. ${ }^{4}$ Medical crusaders appear to be oblivious to the absence of evidence that such coercive policies are effective, and indeed to the strong evidence that they are more likely to be counterproductive.

However, as Snowdon shows, science has long been subordinate to propaganda in the anti-tobacco cause. He quotes a campaigner of the 1970s, who observed, long before the first studies that purported to demonstrate the ill-effects of passive smoking, that 'we were just waiting for science to tell us what we already knew'.
The campaign against passive smoking has grown more strident and more influential in inverse proportion to the scientific evidence. Although large studies in the 1990s had shown all "those who had eyes to see that the passive smoking theory had unravelled', ${ }^{1}$ the anti-smoking bandwagon rolled on regardless.

Snowdon provides entertaining examples of the preposterous claims of anti-smoking campaigners - some suggesting that passive smoking causes diseases (such as breast cancer) that have never been linked to active smoking. From Helena, Montana to Dr Johnston's home city of Glasgow, campaigners have claimed dramatic falls in mortality following the introduction of smoking bans - claims that disintegrate under the slightest scrutiny (which they rarely receive from a cravenly 'on-message' media). More objective reports suggest increases in levels of smoking, particularly among young people, since the introduction of bans. ${ }^{1}$ The long history of prohibitionist measures against alcohol and drugs shows that these have little effect on consumption but provide enormous scope for organised crime (with socially destructive consequences even greater than the original problem).

$\mathrm{Dr}$ Johnston was refused research funding by the Medical Research Council and his key paper was rejected by the (pipe-smoking) editor of the BMJ. After storming out of the editorial offices shouting 'Addict!Addict!Addict!' he devised a plan to burn down the headquarters of the BMA, on which, according to his memoirs, he reflected 'many hundreds of time in bed at night'. Perhaps now is the time for a commemorative statue or plaque in honour of this incendiary campaigner.

\section{REFERENCES}

1. Snowdon, C. Velvet glove, iron fist: a history of antismoking. Ripon: Little Dice, 2009.

2. Johnston, L . Effects of tobacco smoking on health. BMJ 1945; 2(4411):: 98 .

3. Editorial. How do you sleep at night, Mr Blair? Lancet 2003; 362: 1865 .

4. British Medical Association. Under the influence: the damaging effect of alcohol marketing on young people. London: BMA, 2009.

DOI: 10.3399/bjgp09X472809 